\title{
ANALYSING POVERTY DURING COVID-19 PANDEMIC IN INDONESIA BASED ON HISTORICAL PERSPECTIVE
}

\author{
Reni Putri Nurhidayati ${ }^{1}$, Moses Glorino Rumambo Pandin ${ }^{2}$ \\ Faculty of Humanities, Airlangga University \\ reniputrinurhidayati-2020@,fib.unair.ac.id: moses.glorino@fib.unair.ac.id
}

\begin{abstract}
Poverty is one of the indexes that can see how a country succeeds in development. In Indonesia, the poverty rate is high as the impact of the Covid-19 pandemic increases over time. Therefore, a solution is embraced in the form of government policies in tackling poverty in Indonesia. The purpose of this study is to analyze the poverty caused by the Covid-19 pandemic. What is the current state of poverty caused by the Covid-19 pandemic in Indonesia? and what are the previous government policies that have succeeded in reducing poverty in Indonesia? The method used in this study is the literature review method based on the results of critical analysis of journal articles that are relevant to the topic of discussion. The results showed that three government policies have succeeded in lowering the poverty level in Indonesia, namely the PKH program policy, the zakat policy as an indicator of poverty reduction, and the Bank Wakaf Mikro policy. Therefore, this study focuses on the policy as a study for government policy in lowering poverty levels due to the Covid-19 Pandemic.
\end{abstract}

Keywords: Policy, Poverty, Covid-19 Pandemic, Government

\section{INTRODUCTION}

In December 2019, cases of the mysterious disease were first reported in Wuhan, Hubei Province, China. In this first case, the source of the disease is not yet known for certain and is only associated with one of the fish markets in Wuhan. However, Wuhan health experts classify the disease as acute respiratory distress syndrome (ARDS) or severe respiratory distress. Sometime after the first case appeared, the disease quickly spread in the surrounding environment. This can be seen from the number of patients as of December 31, 209 to January 3, 2019 which has increased rapidly with the reported 44 cases. In less than a month, the disease has spread in various regions of other provinces in China and has even spread to other countries, such as Japan, South Korea, and Thailand. (1)

At the beginning of the disease's emergence, the World Health Organization (WHO) temporarily designated the disease like the 2019 novel coronavirus (2019-nCoV). (2) The 2019 figure is used in the name of the disease because the disease was first discovered in 2019. At the end of January 2020, WHO announced to the world that coronavirus cases were included in the Global Emergency status, and then, on February 11, 2019, WHO officially established a new name for the disease under the name Coronavirus Disease (COVID-19). Who changed the 
new name for the disease due to the discovery of the virus that causes the disease. The virus in question is severe acute respiratory syndrome coronavirus-2 (SARS-CoV-2). (3) This is not the first time coronavirus has shocked the world. Extraordinary events caused by coronavirus have also occurred in 2002, namely Severe Acute Respiratory Syndrome (SARS) caused by SARScoronavirus (SARS-CoV) and in 2012, Middle East respiratory syndrome (MERS).

Coronavirus is a zoonosis - a virus that is transmitted from animal to human -, so there are estimates that the virus is transmitted from animal to human. In Covid-19, it is not yet known exactly how the process of spreading the virus comes from animals to humans. However, it can also be estimated that Covid-19 belongs to zoonosis. In addition, in other data developments, the transmission of coronavirus can go from human to human. Human contact and breathing from the nose and mouth are predictions of human-to-human information. This is evident from the occurrence of transmission in health workers who perform Covid-19 positive patient care. Another proof that supports the forecast is the positive result of contracting Covid-19 in a person who came from Shanghai, China, with a German. They claim to have held a meeting in one of the German countries. There is also other evidence that supports the prediction, namely the report of 9 cases of direct interhuman transmission outside China from people who have no travel history from anywhere. (2)

Since Covid-19 was first discovered, the disease has quickly spread throughout the world. In less than half a year, Covid-19 has infected more than 123 countries on several continents, such as the Americas, Europe, Asia, and Africa. In Indonesia, Covid-19 cases were first discovered in early March 2020. (4) This first case infects 2 Indonesian citizens. Both Indonesians are optimistic about Covid-19 due to direct contact activities with Japanese citizens who are positive of Covid-19. After confirmation from the Indonesian government regarding the inclusion of Covid-19 in Indonesia, Covid-19 began to spread throughout Indonesia. Currently, the number of Covid-19 positive patients continues to increase. Based on corona case data from the National Statistics Agency (BPS), as of May 25, 2021, Covid-19 positive confirmation cases amounted to $1,786,187$ people, 44,486 people in treatment, 1,642,074 people recovered, and 49,627 people died as a result of Covid-19. 


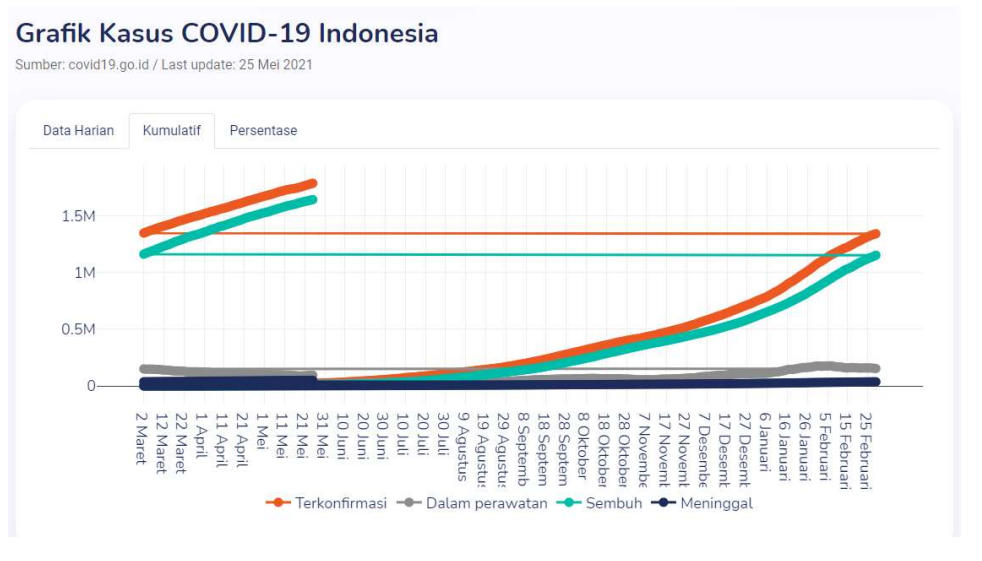

Figure 1. Indonesia Covid-19 Case Graph

Source: covid-19.bps.go.id

The Covid-19 pandemic is causing health problems in patients who have been positively confirmed to be suffering from the disease. Patients with positive results of Covid-19 will experience health problems, especially respiratory system disorders. Covid-19 positive patients usually experience the above symptoms of fever $\left(\geq 38^{\circ} \mathrm{C}\right)$, shortness of breath, cough, sore throat, mild pneumonia, and colds. In addition, the covid-19 disease causes mental health disorders. During the covid-19 pandemic, there are pressures that cause a person to experience disorders, such as excessive fear and panic, difficulty concentrating, stress and boredom due to the application of social policies distancing, changing lifestyles, and sleep patterns disorders. (5)

The Covid-19 pandemic has also impacted various aspects of human life in addition to the health sector. One of them is the economic and social fields. In the financial sector, Covid19 has a significant impact, especially on poverty. Poverty is the inability of an individual or group from an economic point of view to be unable to meet the basic needs of food and other basic needs. Poverty is closely related to the problem of the population having a low average per capita expenditure below the poverty standard. (24) Various policies set by the government to address Covid-19 by enforcing work restrictions resulted in many economic activities being hampered and even ceased operations. This resulted in many companies or other business entities performing employee dismissals, increasing unemployment. (6). Unemployment was then one of the factors that increased poverty. To solve the problem, the government needs to set policies for poverty alleviation that continue to expand to date. 
The policies of the Indonesian government to address the problem of poverty have been widely implemented, but the community can still feel this problem to this day. The problem of poverty is not tiny. The issue of poverty is complex and not an easy one to solve. However, there are government policies that are considered capable of reducing the amount of poverty in society. From these policies, the current government can make new policies or innovations based on policies that have succeeded in reducing the amount of poverty to overcome the current poverty problem caused by the Covid-19 pandemic. This study tries to answer how poverty conditions are caused by the Covid-19 pandemic in Indonesia today and to find out the government's policies that have succeeded in lowering the previous poverty rate. Therefore, this study was conducted to find out the poverty caused by Covid-19 in Indonesia today and to know the government's policies that have succeeded in lowering the previous poverty rate to become a government view to take a new policy in reducing poverty during the Covid-19 pandemic.

\section{METHOD}

The research method used is the literature review. The literature review is conducted based on the results of critical analysis from previous research journals. The criteria of journal articles used for the literature review journal articles that are willing to discuss topics, journal articles published in the last three years, and data sources from trusted and responsible agencies, such as Google Scholar, Badan Pusat Statistika (BPS), Satuan Tugas Penanganan COVID-19, Pusat Penelitian Politik- Lembaga Ilmu Pengetahuan Indonesia (P2P-LIPI), and CNBC Indonesia. From these sources, researchers obtained data that are relevant to the topic of the research problem. Relevant data criteria are in the form of data in the economic and social fields that focus on the phenomenon of poverty due to an unfavorable economy as well as the Covid-19 phenomenon and its impacts. From these criteria, the researchers used keywords such as "Poverty", "Covid", and "Government Policy".

The data collection techniques used by this study are observations and documentation in the form of historical data from several relevant journals. Based on the book "Library Research Methods" on page 3, library research is all activities related to data collection methods, reading data, and recording data as research material. (25)

The analysis techniques in this study use descriptive-qualitative methods. This method is used to explain and analyze the problem of poverty caused by the Covid-19 pandemic. 
Researchers are more specific to analyze the problem of poverty due to the Covid-19 pandemic and several previous government policies that are considered capable of tackling it. The data analysis technique uses references from data analysis leaders named Miles and Huberman. Based on the book "Metode Penelitian Kualitatif di Bidang Pendidikan" on page 51 (26), there is an explanation of data analysis techniques consisting of three stages, namely data reduction, data presentation, and drawing conclusions.

From the data analysis technique according to Miles and Huberman which is used as a reference for the process of analyzing the data of this study, the researchers carried out the data analysis process as follows:

1. Data reduction, researchers select data according to predetermined criteria, namely data in the economic and social fields that focus on the phenomenon of poverty due to an unfavorable economy as well as the Covid-19 phenomenon and its impacts.

2. Presentation of data, the researcher presents data in the form of a summary table in the appendix and a brief review of the indicators of the effectiveness of previous government policies in tackling poverty and conditions of poverty due to the current Covid-19 pandemic.

3. Drawing conclusions, researchers found indicators that led to the effectiveness of previous government policies in tackling poverty.

\section{RESULTS}

The results of this study were obtained through a literature review of 20 journal articles and three official websites of credible agencies. The journal article used as a reference in this study is a journal article published for the last three years. The percentage breakdown of journal articles used include eight journals in 2019 (34.7\%), in 2020 as many as 12 journal articles $(52.1 \%)$, and as many as three website sources consisting of 2020 as many as one website source (4.3\%) and in 2021 as many as two website sources $(8.6 \%)$.

This research has found several results. Starting from the emergence of a disease announced by WHO with the name Severe Acute Respiratory Syndrome Coronavirus-2 (SARS-CoV-2). (3) Then, it was the World Health Organization (WHO) which temporarily designated this new disease as 2019 novel coronavirus (2019-nCoV). (2). Not long after its appearance, Covid-19 spread widely from its home region of China to other countries such as 
Japan, South Korea, and Thailand. (1) During the Covid-19 pandemic, there are pressures that cause a person to experience disturbances, such as excessive fear and panic, difficulty concentrating, stress and boredom. (5) From a political perspective, the Covid-19 pandemic has created a crisis and political turmoil. (14) Another impact of the Covid-19 pandemic is in the economic sector. The Covid-19 pandemic has caused several economic sector activities to stop. (16) Many companies or other business entities have laid off employees, resulting in an increase in unemployment. (6) Companies that suffer losses or force majeure are forced to terminate their workers' employment.(18) This increase in unemployment results in an increase in the number of poverty.

Poverty is an index that can see how successful a country is in development. (7) Poverty is not only understood in the economic field, but can be understood from various dimensions. (8) Theoretically, poverty is divided into two, namely structural poverty and multidimensional poverty. (9)

This study also found the results that the low level of education caused new problems such as increased unemployment and poverty. (11) In addition, the population explosion can increase the decline in per capita income, resulting in a high rate of increase in the minimum standard of living. (12) Low per capita income is one of the indexes to measure poverty. The level of health and low nutrition will result in low endurance and decreased brain thinking, thus hampering activities at work. (13) Low health will reduce productivity. This poses a threat to economic activity as well as the level of poverty.

In addition, this study also found three previous government policies that were considered effective in overcoming poverty, namely the Family Hope Program (PKH), The Effect of Zakat, Infaq on Poverty Reduction, and the Role and Legality of Micro Waqf Banks in Islamic Boarding-Based Poverty Alleviation. First, the implementation of the Family Hope Program (PKH) policy has been going well and in an effort to reduce poverty in Batu City. (19). Second, partially government policy, zakat has an effect on reducing poverty in Aceh, while partially, Infaq has no effect on reducing poverty in Aceh. (20). Third, government policies and the Financial Services Authority (OJK) have succeeded in initiating Micro Waqf Banks (BWM) with Islamic boarding schools in Indonesia as an effort to overcome poverty problems. (21) . Based on these three policies, the current government can review the historical data of these policies through the use of Historical Science. (22) Through historical documents, the government can find out what are the success indicators of previous policies. (23) 


\section{DISCUSSION}

\section{Concept of Poverty}

Poverty is one of the indexes that can see how a country succeeds in development. (7) The definition of poverty is important to know clearly. Poverty can be defined as a level of life of an individual or group that is below the minimum standard of living needs. Standard of living conditions can be seen based on food needs, health, education, etc. The inability of individuals and groups to meet these basic living standards is called poverty.(24) In addition, poverty is a complex problem faced by many countries globally for a long time. This is because poverty is understood in the economic field and can be understood from various dimensions. (8)

Based on Law No.24 of 2004, poverty is a socioeconomic condition of a person or group of people who do not fulfill their fundamental rights to maintain and develop a dignified life. Basic needs that become the right of a person or group of people in question are the need for food, clothing, education, health, availability of clean water, land, protection from crimes, a sense of security, and the right to participate in social and political life.

Theoretically, poverty is divided into two, namely structural poverty and multidimensional poverty. (9) Structural poverty shall be defined as poverty caused by the state of helplessness of individuals or groups to lead a decent life or meet the standard line of living needs. This type of poverty defines an individual as a person who is powerless to change his or her life's fate. Here, the lazy factor of work is not a cause of this type of poverty. This poverty can be seen from the social structure in the community. Social structure in society can be an obstacle to the mobility of a relatively poor society to change its fate. This is because social structures sometimes impose restrictions on the rights of individuals in the lower classes.

This fact is in line with Karl Marx's thoughts on the social structure that causes poverty. Marx thinks that the political and spiritual power system is a picture of the class power structure that exists in society. (10) MenMarx divides society into two classes: the bourgeoisie and the proletariat. The bourgeoisie is defined as the owners of production tools. The bourgeoisie became the complete owners of a company and the workers as its workers. The bourgeoisie gained a high surplus over its companies by unfairly targeting workers, such as giving low wages and not by the laborers' labor. The bourgeoisie also occupied a higher social class so that their rights were fulfilled. This is inversely proportional to the polestar. The proletariat consisted of laborers, meaning that these people had no right at all to the means of production. 
These people also experienced oppression by the bourgeoisie; even these people were difficult to obtain fundamental rights of life. The lives of this proletariat can be said to be misery because of the poverty they experience. Thus the division of society by Marx can describe the condition of social structure in the community until now.

\section{Factors Causing Poverty}

Poverty is a complex problem. From the past until now, this problem still exists, even continues to increase. Of course, this problem does not arise just like that, but there are factors behind the problem. Broadly speaking, the factors that cause poverty are as follows:

a. Low level of education. Education is a provision for individuals before entering the field of employment. Education is also a basic necessity of each individual. In fact, there are still individuals who have never experienced education. This is common in people living in rural or rural areas. As a result, many people living in the area are left behind. This can be seen from the number of poor people in rural areas being higher than the number of poor people in urban areas. (6) Education becomes one of the containers of self-development for individuals to form self-quality. This self-quality can be seen from the skills, knowledge insights, morals, and behaviors of individuals. All of that can be obtained through education. The quality of each individual is superior to this will reflect how successful education is. If each individual has special attributes, it can be said that Human Resources also excel. However, the quality of human resources is still quite challenging to achieve the word "superior." This is because there is an uneven education in each region. This resulted in a low level of education. This low level of education then leads to new problems such as increased unemployment and poverty. (11) Therefore, it can be said that low education level is one of the critical factors causing the problem of poverty.

b. Increasing population. The high population is one of the contributing factors to poverty. This can happen because an increase in the population without being followed by sufficient quality human resources (HR) will result in inequality. This is also related to the first factor that has been explained. In addition, the high birth rate also increases the population. The increasing birth rate in each family will affect the number of economic needs in the family. If the family's financial condition is below the minimum standard of living, it can be said that the family has a threat from poverty. The cause is that the family cannot afford to finance each family member's needs. The increase in high and 
uncontrolled population can also lead to population explosions. The explosion of the people then increased the decline in per capita income. (12) Low capita income is one of the indexes for measuring poverty. Therefore, the increase in the population is categorized as one of the factors of poverty.

c. Health quality is low. A low rate of health leads to poverty. This is because low levels of health and nutrition will result in low endurance and decreased brain thinking, thus inhibiting activity at work. (13) Low health will decrease productivity. This poses a threat to economic activity. Of course, productivity also affects the results obtained. If this happens to a category of individuals who fall below the minimum standard of living, this will be a problem towards poverty. Therefore, the health sector becomes the determining factor in the issue of poverty.

Of these three factors, it can be known that poverty is a complex problem. This is because the factors that cause poverty are interrelated with each other. These three factors are common factors that cause the onset of poverty. In fact, there are still several other factors that cause the problem of poverty.

\section{Poverty in Indonesia Due to Covid-19 Pandemic}

Poverty has been going on for a long time in Indonesia. According to historical records, poverty is one of the legacies of colonialism that has occurred in Indonesia. (9) Poverty is still a persistent problem facing Indonesia. This proves that poverty is not a trivial issue. Serious efforts are needed from various components of society and government to work together in tackling this poverty.

Based on the National Statistics Agency records, as of September 2020, there is an increase in the number of poor people in Indonesia, as many as 27.55 million people. This increased by 1.13 million people from March 2020 and by 2.76 million people from September 2019. Further explanation can be seen in the following table: 


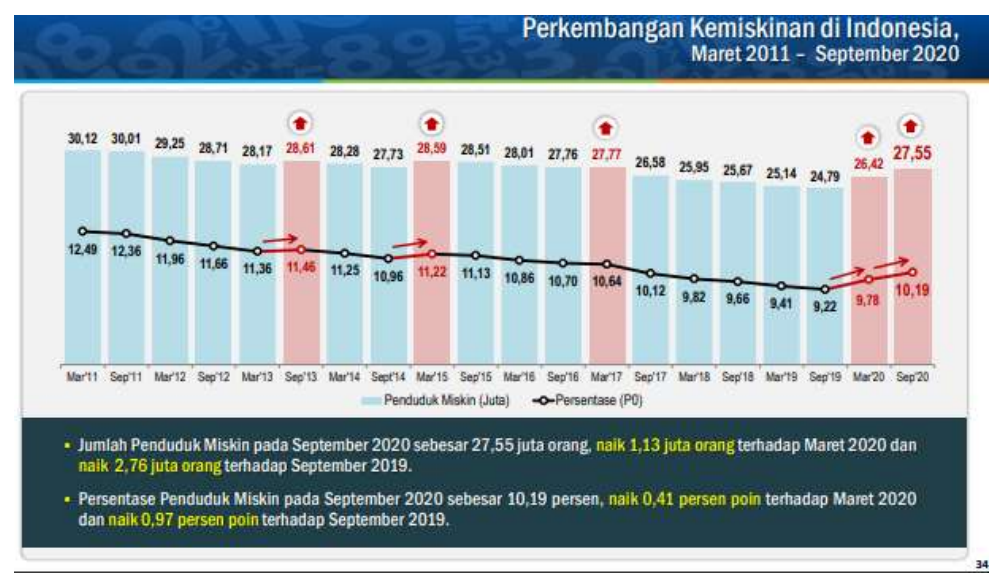

Figure 2. Poverty Development in Indonesia

Source: bps.go.id

The graphic image can be seen as an increase in the number of poor people in Indonesia as of September 2020. This means that the increase occurred when the Covid-19 outbreak has entered Indonesia.

The Covid-19 pandemic has had a significant impact on the order of human life. Various aspects of life are also affected by this disease. In Indonesia, the effect of the Covid19 pandemic has been felt for over a year. Many changes occur in various areas that affect life. In terms of health, the Covid-19 pandemic is the main problem in the health sector today. Its rapid spread to multiple worlds and its fatal effects cause the sufferer to die a severe threat. The discovery of an effective drug to overcome this outbreak is the duty of doctors today. In terms of politics, the Covid-19 pandemic has created a crisis and political turmoil. (14) This can be seen from the public response to the management policy set by the government. (15). There is also a discourse that occurs among the political elite in addressing and making policies to overcome Covid-19. In terms of the economy, the Covid-19 pandemic has brought some economic sector activity to a standstill. Economic activities such as export-import activities of goods, public transportation services, face-to-face buying and selling activities, and so on. (16)

The impact of the Covid-19 pandemic in the economic field is of particular concern in this study. In the financial area, directly, the Covid-19 pandemic has a significant impact on increasing the amount of poverty. In Indonesia, the percentage increase in the number of poor people from 0.41 percentage points in March 2020 to the rise of 10.19 percent in September 2020. This is evidence that the economic sector is affected by the Covid-19 pandemic. 
Indonesia suffered losses due to the Covid-19 pandemic. This loss is macro or only occurs in the country. (16) The deduction is that the state's income from taxes decreases. This tax reduction occurred due to large-scale social restrictions imposed by the Indonesian government. With the establishment of PSBB in some areas of Indonesia such as Jabodetabek, Surabaya Raya, Bali, Bandung, Malang Raya, Yogyakata, and so on. (17) The existence of this PSSB results in the closure of the industry or most of the industry, so that this impacts the losses suffered by the company. As a result, companies that suffer losses or force major are forced to terminate their employment. (18) This reason becomes controversial because losses are considered not to be the right reason to decide the workers. However, clearly, the termination of employment by this company increased the number of unemployed in Indonesia. This number of unemployed then increases the rate of poverty development in Indonesia.

\section{Poverty Alleviation Efforts Through Historical Perspective}

The Indonesian government has carried out poverty alleviation efforts for a long time by making policies that are considered to be able to overcome the problem of poverty. These policies include Direct Cash Assistance (BLT), Family Hope Program (PKH), Smart Indonesia Program (PIP), and other programs. These programs aim to improve the lower class to overcome poverty. (12) However, there are also some policies that the government has made to be less effective in reducing poverty in Indonesia. This is due to the government's lack of attention to the characteristics of local communities that will receive assistance. Eventually, the aid program was utilized by several irresponsible people as a profit field. Therefore, a new policy or program is needed as an effort to alleviate poverty that is expected to be more effective among communities affected by the Covid-19 pandemic.

In recent history, the Indonesian government has managed to overcome poverty in several regions. Some of these areas showed positive results from the implementation of government programs. This is evidenced by research conducted by Cahyo Sasmito on the community in Batu City. (19) The study results show that the implementation of the Family of Hope Program $(\mathrm{PKH})$ has been running well and the road to reduce the poverty rate in Batu City. PKH program can run efficiently and efficiently because of the communication and good relationship between PKH Escorts from the Social Service of Batu City Government and PKH participants. This PKH companion performs its duties well by accompanying PKH participants, providing counseling to $\mathrm{PKH}$ participants on how the participants' requirements and requirements must be met, giving advice to participants on how to process assistance, and 
providing counseling related to the development of expertise of PKH participants. Thus, PKH assistance to the community in Batu city can be said to have succeeded by the target expected by the government.

In addition to these examples, there is also research conducted by Toha Afifudin and Norma Sari on the influence of zakat, infaq on poverty reduction in Aceh in the period 20072017. The results showed that, partially, zakat has an effect on reducing poverty in Aceh while in part, Infaq has no effect on reducing poverty in Aceh. (20) Zakat is one of the worships in Islam that is bound by the aspect of ditribution, namely the distribution of funds from zakat givers to zakat recipients. Zakat has a significant impact on reducing poverty. With every 1 percent increase in zakat funds collected, the poverty rate decreased by 16.5 percent. However, infaq is considered not significant enough to reduce the poverty rate in Aceh.

The research conducted by Siska Lis Sulistiani et al. on the role and legality of Bank Wakaf Mikro in poverty alleviation based pesantren in Indonesia. This study showed that the government and the Financial Services Authority (OJK) successfully initiated Bank Wakaf Mikro (BWM) with pesantren institutions in Indonesia as a form of effort to overcome the problem of poverty. (21) BWM is a sharia microfinance institution (LKMS) that aims to provide access to capital or costs in advance for small communities that do not have access to finance at other formal financial institutions. BWM established by the OJK successfully reduces poverty by providing sharia-principled financing services, namely without using interest, and is only obliged to pay as much as $3 \%$ per year for administrative costs.

From these three studies, it can be said that several previous Indonesian government policies have been proven to reduce poverty as it is known that historical science has benefits to the destruction of the past and the supply of data material to past events. (22) Data related to events that have occurred in the past can be reviewed through historical documents. Historical documents explain the instructions on an event in the past and help give a recollection to the historical actors involved in the event. (23) If connected with the topics discussed in this study, history can be the government's paradigm to create new policies to overcome the problem of poverty in Indonesia. The history of such policies can be used as a review for the government to find solutions to the problem of poverty in Indonesia due to the Covid-19 pandemic. 


\section{CONCLUSION}

The Covid-19 pandemic is a widespread disease outbreak in various regions of the world in the 21 st century. Pandemic Covid-19 has a significant impact on the order of human life because it has given changes to aspects of life. In the field of health, the Covid-19 pandemic causes respiratory infections that cause death. In addition, in the economic area of the Covid19 pandemic, poverty is increasing. This poverty occurs because, during the Covid-19 pandemic, there have been losses suffered by the company. As a result, the company was forced to terminate its employees. This causes the number of unemployed to increase - this increasing number of unemployed causes the poverty rate to be higher.

Based on the Central Bureau of Statistics data, as of September 2020, there has been an increase in the number of poor people in Indonesia by 27.55 million people. This increased by 1.13 million people from March 2020 and by 2.76 million people from September 2019. This is undoubtedly a result of the Covid-19 pandemic that has entered Indonesia. As a result, the poverty rate in Indonesia is getting higher. The government must establish a new policy to address Indonesia's high poverty levels.

The government can apply the historical paradigm in making policies to overcome poverty levels. Through the historical trajectory, the government can see the past policies that have succeeded in reducing poverty in Indonesia. These policies include PKH program policies, zakat policies as indicators of poverty reduction, and Bank Wakaf Micro policies that are useful to provide access to capital for small communities. Therefore, it is expected that the government can review the procedure's historical data to become a government view to take a new policy in reducing poverty during the Covid-19 pandemic.

The limitation of this research lies in the limited sources of articles that discuss government policies to reduce poverty in Indonesia. In fact, there are still previous government policies that have succeeded in tackling poverty in Indonesia. However, due to the criteria for article sources that have a limitation on publication in the last three years, namely 2019-2021, it makes it difficult for researchers to find article sources that will be used as literature review studies. This research is limited to discussing three previous government policies that were effective in reducing poverty in Indonesia. The three policies are the PKH program policy, the zakat policy as an indicator of poverty reduction, and the Micro Waqf Bank policy.

Based on the results of this study in the form of three previous government policies that were considered effective in reducing poverty levels in Indonesia, the researcher recommends 
the government to further review the historical data of these policies so that they can become a government view to take a new policy in reducing poverty in Indonesia the time of the Covid19 pandemic. In addition, the researcher hopes that this research can be a reference in further research on topics related to poverty and efforts to overcome it.

\section{REFERENCES}

1. Susilo A, Rumende CM, Pitoyo CW, Santoso WD, Yulianti M, Herikurniawan H, et al. Coronavirus Disease 2019: Tinjauan Literatur Terkini. J Penyakit Dalam Indonesia. 2020;7(1):45.

2. Diah Handayani, Dwi Rendra Hadi, Fathiyah Isbaniah, Erlina Burhan HA, Departemen. Penyakit Virus Corona 2019. J Respirologi Indones. 2020;40(2):119-29.

3. Yuliana Y. Corona virus diseases (Covid-19): Sebuah tinjauan literatur. Wellness Heal Mag. 2020;2(1):187-92.

4. Satuan Tugas Penanganan COVID-19. Tanya Jawab [Internet]. 2021. Available from: https://covid19.go.id/tanya-jawab?search=Apa yang dimaksud dengan pandemi

5. Ilpaj SM, Nurwati N. Analisis Pengaruh Tingkat Kematian Akibat Covid-19 Terhadap Kesehatan Mental Masyarakat Di Indonesia. Focus J Pekerj Sos. 2020;3(1):16.

6. Tarigan H, Sinaga JH, Rachmawati RR. Dampak Pandemi Covid-19 terhadap Kemiskinan di Indonesia. Pus Sos Ekon dan Kebijak Pertan. 2020;(3):457-79.

7. Septiadi D, Nursan M. Pengentasan Kemiskinan Indonesia: Analisis Indikator Makroekonomi Dan Kebijakan Pertanian. J Hexagro. 2020;4(1).

8. Aidha CN, Ningrum DR, Armintasari F, Herawati, Ramdlaningrum H, Sagala M, et al. Indeks Kemiskinan Multidimensi Indonesia 2015-2018. 2020. 1-252 p.

9. Nikodemus Niko. Kemiskinan Perempuan Dayak Benawan di Kalimantan Baratsebagai Bentuk Kolonialisme Baru. J Pemikir Sosiol. 2019;6(1):58-76.

10. Kambali M. Pemikiran Karl Marx Tentang Struktur Masyarakat (Dialektika Infrastruktur Dan Suprastruktur). J Pemikir dan Penelit Ekon Islam [Internet]. 2020;8(2):63-80. Available from: https://media.neliti.com/media/publications/332489pemikiran-karl-marx-tentang-struktur-mas-fb1b694e.pdf

11. Hasibuan SN, Juanda B, Mulatsih S. Analisis Sebaran Dan Faktor Penyebab Kemiskinan Di Kabupaten Bandung Barat. J Agribisnis Indones. 2019;7(2):79-91.

12. Middleton EL. Analisis Pengaruh Pendidikan, Pertumbuhan Penduduk dan Investasi terhadap Kemiskinan di Kalimantan Selatan. 2019;2(4):842-51.

13. Zahra A, Fatin A A, Afuwu H, Auliyah R R. Struktur Kemiskinan Indonesia: Berapa Besar Pengaruh Kesehatan, Pendidikan dan Kelayakan Hunian? J Inov Ekon. 2019;4(02):67-74.

14. Rusdi R. Pandemi Penyakit dalam Sejarah dan Dampaknya Terhadap Gejolak Sosial Politik. Diakronika. 2020;20(1):50.

15. Haripin M. Dampak Politik-Keamanan COVID-19 [Internet]. Pusat Penelitian PolitikLembaga Ilmu Pengetahuan Indonesia (P2P-LIPI). 2020. Available from: http://www.politik.lipi.go.id/kolom/kolom-2/politik-nasional/1383-dampak-politikkeamanan-covid-19

16. Hadiwardoyo W. Kerugian Ekonomi Nasional Akibat Pandemi Covid-19. Baskara J Bus Entrep. 2020;2(2):83-92.

17. Sembiring LJ. Cek! Kota-kota yang Kena PSBB Ketat, Daerah Kamu Bukan? [Internet]. CNBC Indonesia. 2021. Available from: 
https://www.cnbcindonesia.com/news/20210106134527-4-213882/cek-kota-kotayang-kena-psbb-ketat-daerah-kamu-bukan

18. Juaningsih IN. Analisis Kebijakan PHK Bagi Para Pekerja Pada Masa Pandemi Covid19 di Indonesia. Bul Huk dan Keadilan. 2020;4(1):189-96.

19. Sasmito C, Nawangsari ER. Implementasi Program Keluarga Harapan Dalam Upaya Mengentaskan Kemiskinan Di Kota Batu. JPSI (Journal Public Sect Innov. 2019;3(2):68.

20. Afifudin T, Sari N. Pengaruh Zakat, Infaq Terhadap Penurunan Kemiskinan Di Aceh 2007201. j-EBIS [Internet]. 2019; Available from: http://journal.iainlangsa.ac.id/index.php/ebis

21. Sulistiani LS dkk. Peran dan Legalitas Bank Wakaf Mikro dalam Pengentasan Kemiskinan Berbasis Pesantren di Indonesia. J Bimas Islam. 2019;12(1):2.

22. Purwanto B. Mengapa Indonesia Memerlukan Ilmu Sejarah? Beberapa Gagasan untuk 'Hilirisasi' Historiografi. Bakti Budaya. 2020;3(1):4.

23. Setyaningsih W. Mengulik Sejarah Melalui Pemanfaatan Perpustakaan. Pustabiblia J Libr Inf Sci. 2019;3(2):205-22.

24. Badan Pusat Statistik. Kemiskinan dan Ketimpangan [Internet]. Badan Pusat Statistik. 2021 [cited 2021 Jun 7]. Available from:

https://www.bps.go.id/subject/23/kemiskinan-dan-ketimpangan.html\#subjekViewTab1

25. Zed M. Metode Penelitian Kepustakaan. Jakarta: Yayasan Obor Indonesia; 2008.

26. Sidiq U, Choiri MM. Metode Penelitian Kualitatif di Bidang Pendidikan. Ponorogo: CV. Nata Karya; 2019. 
ATTACHMENT

Table 1. Summary of Results from Journal Article

\begin{tabular}{|c|c|c|c|}
\hline $\begin{array}{c}\text { Author/Researche } \\
\text { r } \\
\text { (Year) }\end{array}$ & $\begin{array}{l}\text { Research } \\
\text { Method }\end{array}$ & Title & Results \\
\hline $\begin{array}{l}\text { Susilo, Rumende, } \\
\text { Pitoyo, Santoso, } \\
\text { Yulianti, } \\
\text { Herikurniawan, et al } \\
\text { (2020) }\end{array}$ & $\begin{array}{l}\text { Literature } \\
\text { Review }\end{array}$ & $\begin{array}{c}\text { Coronavirus Disease } \\
\text { 2019: Tinjauan Literatur } \\
\text { Terkini. J Penyakit Dalam } \\
\text { Indonesia. }\end{array}$ & $\begin{array}{l}\text { Contains the time of the } \\
\text { spread of Covid-19 in } \\
\text { various regions of China } \\
\text { and has even spread to } \\
\text { other countries, such as } \\
\text { Japan, South Korea, and } \\
\text { Thailand }\end{array}$ \\
\hline $\begin{array}{c}\text { Diah Handayani, } \\
\text { Dwi Rendra Hadi, } \\
\text { Fathiyah Isbaniah, } \\
\text { Erlina Burhan HA, } \\
\text { Department } \\
\text { (2020) }\end{array}$ & - & $\begin{array}{l}\text { Penyakit Virus Corona } \\
2019\end{array}$ & $\begin{array}{l}\text { Contains a statement by } \\
\text { the World Health } \\
\text { Organization (WHO) } \\
\text { which temporarily } \\
\text { designated this new } \\
\text { disease as } 2019 \text { novel } \\
\text { coronavirus }(2019-\mathrm{nCoV}) .\end{array}$ \\
\hline $\begin{array}{l}\text { Yuliana Y } \\
\text { (2020) }\end{array}$ & $\begin{array}{l}\text { Literature } \\
\text { Review }\end{array}$ & $\begin{array}{l}\text { Corona virus diseases } \\
\text { (Covid-19): Sebuah } \\
\text { tinjauan literatur. }\end{array}$ & $\begin{array}{l}\text { Containing the statement } \\
\text { that the WHO announced } \\
\text { a new name for the } \\
\text { disease discovered by the } \\
\text { name of the Severe Acute } \\
\text { Respiratory Syndrome } \\
\text { Coronavirus-2 (SARS- } \\
\text { CoV-2) }\end{array}$ \\
\hline $\begin{array}{c}\text { virus Ilpaj SM, } \\
\text { Nurwati N (2020) }\end{array}$ & $\begin{array}{c}\text { Literature } \\
\text { Review }\end{array}$ & $\begin{array}{c}\text { Analisis Pengaruh Tingkat } \\
\text { Kematian Akibat Covid- } \\
19 \text { Terhadap Kesehatan } \\
\text { Mental Masyarakat Di }\end{array}$ & $\begin{array}{l}\text { Contains an explanation } \\
\text { that during the covid-19 } \\
\text { pandemic, there are } \\
\text { pressures that cause a }\end{array}$ \\
\hline
\end{tabular}




\begin{tabular}{|c|c|c|c|}
\hline & & Indonesia & $\begin{array}{l}\text { person to experience } \\
\text { disturbances, such asfear } \\
\text { and panic excessive, } \\
\text { difficulty concentrating, } \\
\text { stress and boredom }\end{array}$ \\
\hline $\begin{array}{c}\text { Tarigan H, Sinaga } \\
\text { JH, Rachmawati RR } \\
\text { (2020) }\end{array}$ & - & $\begin{array}{c}\text { Dampak Pandemi Covid- } \\
19 \text { terhadap Kemiskinan } \\
\text { di Indonesia }\end{array}$ & $\begin{array}{l}\text { Contains an explanation } \\
\text { of many companies or } \\
\text { other business entities } \\
\text { firing employees resulting } \\
\text { in an increase in } \\
\text { unemployment }\end{array}$ \\
\hline $\begin{array}{c}\text { Septiadi D, Nursan } \\
\text { M } \\
(2020)\end{array}$ & $\begin{array}{l}\text { Multiple linear } \\
\text { regression } \\
\text { analysis. }\end{array}$ & $\begin{array}{l}\text { Pengentasan Kemiskinan } \\
\text { Indonesia: Analisis } \\
\text { Indikator Makroekonomi } \\
\text { Dan Kebijakan Pertanian }\end{array}$ & $\begin{array}{c}\text { Containing the definition } \\
\text { of poverty }\end{array}$ \\
\hline $\begin{array}{c}\text { Aidha CN, Ningrum } \\
\text { DR, Armintasari F, } \\
\text { Herawati, } \\
\text { Ramdlaningrum H, } \\
\text { Sagala M, et al } \\
\text { (2020) }\end{array}$ & - & $\begin{array}{c}\text { Indeks Kemiskinan } \\
\text { Multidimensi Indonesia } \\
\text { 2015-2018 }\end{array}$ & $\begin{array}{l}\text { Contains an explanation } \\
\text { of poverty not only } \\
\text { understood only in the } \\
\text { economic field, but can be } \\
\text { understood from the } \\
\text { various dimensions of }\end{array}$ \\
\hline $\begin{array}{l}\text { Nicodemus Niko } \\
\text { (2019) }\end{array}$ & $\begin{array}{l}\text { Qualitatively } \\
\text { descriptive of }\end{array}$ & $\begin{array}{c}\text { Kemiskinan Perempuan } \\
\text { Dayak Benawan di } \\
\text { Kalimantan Barat sebagai } \\
\text { Bentuk Kolonialisme } \\
\text { Baru.. }\end{array}$ & $\begin{array}{l}\text { Contains the theoretical } \\
\text { division of poverty into } \\
\text { two }\end{array}$ \\
\hline $\begin{array}{c}\text { Hasibuan SN, } \\
\text { Juanda B, Mulatsih } \\
\text { S (2019) }\end{array}$ & Quantitative & $\begin{array}{c}\text { Analisis Sebaran Dan } \\
\text { Faktor Penyebab } \\
\text { Kemiskinan Di Kabupaten } \\
\text { Bandung Barat }\end{array}$ & $\begin{array}{l}\text { Contains a statement that } \\
\text { the low level of education } \\
\text { raises new problems such } \\
\text { as increased } \\
\text { unemployment and } \\
\text { poverty }\end{array}$ \\
\hline Middleton EL. & Quantitative & Analisis Pengaruh & Contains an explanation \\
\hline
\end{tabular}




\begin{tabular}{|c|c|c|c|}
\hline (2019) & & $\begin{array}{c}\text { Pendidikan, Pertumbuhan } \\
\text { Penduduk dan Investasi } \\
\text { terhadap Kemiskinan di } \\
\text { Kalimantan Selatan. }\end{array}$ & $\begin{array}{l}\text { of the population } \\
\text { explosion that increases } \\
\text { the decline in per capita } \\
\text { income }\end{array}$ \\
\hline $\begin{array}{l}\text { Zahra A, Fatin AA, } \\
\text { Afuwu H, Auliyah } \\
\text { R R. (2019) }\end{array}$ & Quantitative & $\begin{array}{c}\text { Struktur Kemiskinan } \\
\text { Indonesia: Berapa Besar } \\
\text { Pengaruh Kesehatan, } \\
\text { Pendidikan dan Kelayakan } \\
\text { Hunian? }\end{array}$ & $\begin{array}{l}\text { The data contain low } \\
\text { levels of health and } \\
\text { nutrition will result in } \\
\text { lower immune system and } \\
\text { thinking brain is } \\
\text { decreased thereby } \\
\text { inhibiting the activity of } \\
\text { the working }\end{array}$ \\
\hline $\begin{array}{l}\text { Rusdi R. } \\
\text { (2020) }\end{array}$ & - & $\begin{array}{l}\text { Pandemi Penyakit dalam } \\
\text { Sejarah dan Dampaknya } \\
\text { Terhadap Gejolak Sosial } \\
\text { Politik. Diakronika }\end{array}$ & $\begin{array}{l}\text { Contains research from a } \\
\text { political perspective that } \\
\text { the Covid-19 pandemic } \\
\text { has created a crisis and } \\
\text { political turmoil. }\end{array}$ \\
\hline $\begin{array}{c}\text { Hadiwardoyo W } \\
\text { (2020) }\end{array}$ & Qualitative & $\begin{array}{c}\text { Kerugian Ekonomi } \\
\text { Nasional Akibat Pandemi } \\
\text { Covid-19 }\end{array}$ & $\begin{array}{l}\text { Containing research on } \\
\text { the Covid-19 pandemic, } \\
\text { several economic sector } \\
\text { activities have stopped. }\end{array}$ \\
\hline $\begin{array}{c}\text { Juaningsih IN } \\
\text { (2020) }\end{array}$ & - & $\begin{array}{l}\text { Analisis Kebijakan PHK } \\
\text { Bagi Para Pekerja Pada } \\
\text { Masa Pandemi Covid-19 } \\
\text { di Indonesia. }\end{array}$ & $\begin{array}{c}\text { Contains research on } \\
\text { companies that experience } \\
\text { losses or force majeure } \\
\text { forced to terminate their } \\
\text { workers }\end{array}$ \\
\hline $\begin{array}{c}\text { Sasmito C, } \\
\text { Nawangsari ER } \\
\text { (2019) }\end{array}$ & $\begin{array}{l}\text { Qualitative } \\
\text { descriptive. }\end{array}$ & $\begin{array}{c}\text { Implementasi Program } \\
\text { Keluarga Harapan Dalam } \\
\text { Upaya Mengentaskan } \\
\text { Kemiskinan Di Kota Batu }\end{array}$ & $\begin{array}{l}\text { Contains implementation } \\
\text { of the Family Hope } \\
\text { Program (PKH) has been } \\
\text { going well and the way in } \\
\text { efforts to reduce poverty } \\
\text { in Batu }\end{array}$ \\
\hline Afifudin T, Sari N & Descriptive & Pengaruh Zakat, Infaq & Containing \\
\hline
\end{tabular}




\begin{tabular}{|c|c|c|c|}
\hline (2019) & $\begin{array}{l}\text { quantitative and } \\
\text { test multiple } \\
\text { linear } \\
\text { regression is } \\
\text { used }\end{array}$ & $\begin{array}{l}\text { Terhadap Penurunan } \\
\text { Kemiskinan Di Aceh } \\
\text { 2007-2017 }\end{array}$ & $\begin{array}{l}\text { partially, zakat has an } \\
\text { effect on reducing poverty } \\
\text { in Aceh while partially, } \\
\text { Infaq has no effect on } \\
\text { reducing poverty in Aceh. }\end{array}$ \\
\hline $\begin{array}{l}\text { Sulistiani LS et al. } \\
\text { (2019) }\end{array}$ & $\begin{array}{l}\text { Juridical } \\
\text { normative }\end{array}$ & $\begin{array}{l}\text { Peran dan Legalitas Bank } \\
\text { Wakaf Mikro dalam } \\
\text { Pengentasan Kemiskinan } \\
\text { Berbasis Pesantren di } \\
\text { Indonesia }\end{array}$ & $\begin{array}{l}\text { Contains research on the } \\
\text { government and the } \\
\text { Financial Services } \\
\text { Authority (OJK) } \\
\text { successfully initiating } \\
\text { Micro Waqf Banks } \\
\text { (BWM) with Islamic } \\
\text { boarding schools in } \\
\text { Indonesia as an effort to } \\
\text { overcomepoverty problem }\end{array}$ \\
\hline $\begin{array}{l}\text { Purwanto'sB } \\
\text { (2020) }\end{array}$ & - & $\begin{array}{c}\text { Mengapa Indonesia } \\
\text { Memerlukan Ilmu } \\
\text { Sejarah? Beberapa } \\
\text { Gagasan untuk 'Hilirisasi' } \\
\text { Historiografi }\end{array}$ & $\begin{array}{l}\text { Contains an explanation } \\
\text { of the benefits of History. }\end{array}$ \\
\hline $\begin{array}{l}\text { Setyaningsih W } \\
\text { (2019) }\end{array}$ & $\begin{array}{c}\text { Collecting } \\
\text { observational } \\
\text { data, } \\
\text { documentation } \\
\text { studies, and } \\
\text { interviews. }\end{array}$ & $\begin{array}{c}\text { Mengulik Sejarah Melalui } \\
\text { Pemanfaatan } \\
\text { Perpustakaan }\end{array}$ & $\begin{array}{l}\text { Contains an explanation } \\
\text { of the function of } \\
\text { historical documents. }\end{array}$ \\
\hline
\end{tabular}


Table 2. Percentage of Sources

\begin{tabular}{|c|c|c|c|c|}
\hline No. & Kategory & year & Sum & Percentage \\
\hline 1. & Journal Articles & 2019 & 8 & $34,7 \%$ \\
\hline 2. & Journal Articles & 2020 & 12 & $52,1 \%$ \\
\hline 3. & Situs Website & 2020 & 1 & $4,3 \%$ \\
\hline 4. & Situs Website & 2021 & 2 & $8,6 \%$ \\
\hline
\end{tabular}

